\title{
The Oregon Earned Income Credit's Impact on Child Poverty
}

\author{
David W. Rothwell ${ }^{1 *}{ }^{\text {, Bruce A. Weber }}{ }^{2}$, Leanne S. Giordono ${ }^{3}$
}

${ }^{1}$ School of Social and Behavioral Health Sciences, Oregon State University, Corvallis, Oregon, United States of America

${ }^{2}$ Department of Applied Economics, Oregon State University, Corvallis, Oregon, United States of America

${ }^{3}$ School of Social and Behavioral Health Sciences, Oregon State University, Corvallis, Oregon, United States of America

Corresponding Author:

E-mail: rothweld@oregonstate.edu (DR) 


\begin{abstract}
Oregon has a refundable earned income tax credit (OEIC) that is equal to 8 percent of the Federal Earned Income Tax Credit (EITC). In 2017, Oregon introduced a unique supplement to the OEIC that provided an additional 3\% of the Federal EITC to families with children under age 3. To date, there has been no research examining the impact of the OEIC on child poverty. Using data from the Current Population Survey, we simulate the static effects of this unique state OEIC on overall poverty, child poverty, and early child poverty rates in Oregon. We find that the OEIC does not yield a change in the estimated headcount poverty rate for either children or young children. However, focusing exclusively on changes in poverty rates underestimates the impact of the OEIC. The overall estimated impact on the poverty gap and poverty severity is greater about 2 to 4 percent. Children and young children in families closer to the poverty threshold experience reductions in the poverty gap and poverty severity by about 6 to 9 percent. We tested four policy simulations and found that a simulated OEIC set at 11\% of EITC for children and $29 \%$ for young children would significantly decrease the child and young child poverty rates by 4 percent and 9 percent, respectively. To reduce more poverty via the OEIC would require substantially more resources which may not be feasible.

Keywords: Earned Income Tax Credit; Oregon Earned Income Credit; child poverty
\end{abstract}




\section{Introduction}

Children in the United States are at a disproportionately high risk for poverty. Depending on the measure employed - Official Poverty Measure (OPM) or Supplemental Poverty Measure (SPM) - recent estimates suggest that between 16.1 (SPM) and 20.1 (OPM) percent of American children were poor, compared to 14.3 (SPM) and 13.7 (OPM) percent for all people [1]. The high rate of child poverty is a concern not only because poverty affects child well-being, but also because experiencing poverty during childhood increases the risk for lifelong hardship [2,3]. Even more importantly, the timing of poverty during childhood matters, as poverty early in the life course may have more negative impacts compared to later childhood [4,5]. The state of Oregon recently changed its Earned Income Credit (OEIC) policy to target more resources to families with young children aged three and below [6]. In this paper, we aim to understand the impact of the OEIC on child poverty in Oregon. We found that the current structure of the OEIC does not reduce much child poverty because the level of benefit is not sufficient to lift children out of poverty; however, by adding resources to families the OEIC reduces poverty severity and depth. Our simulations suggest the precise amounts of credit that would be needed to have a meaningful impact on child poverty.

The paper begins by briefly reviewing the literature on the impact of the Federal Earned Income Tax Credit (EITC) on employment, income, and poverty. We then provide the economic and tax policy context in Oregon that led the Oregon Legislature to create an enhanced OEIC for families with young children. This is followed by a methods section that outlines the research design for simulating the static effects of the OEIC on poverty and child poverty in Oregon and a results section that reports these impact estimates. The paper closes with implications for child poverty and suggestions for future research. 


\section{The Earned Income Tax Credit as an anti-poverty strategy}

The Federal government initiated the EITC in 1975 to offset the Social Security payroll taxes that were seen as quite regressive and that reduced the spendable income of low-income families [7,8]. As policymakers became more concerned about the work disincentive effects of social safety net programs in the last quarter of the $20^{\text {th }}$ Century, the U.S. social safety net began to be restructured toward a system that required work as a condition for receipt of benefits. In 1996, at a time when Congress enacted a major reform in the primary cash transfer program for low-income families with children created in the New Deal (Aid to Families with Dependent Children - AFDC), it also enacted a series of increases in the EITC (which is conditional on work and earnings). Small increases in 1986 and 1990 were followed by very substantial increases enacted in 1993 that were phased in over the 1993-96 period.

The EITC provides cash to families in the form of a refundable credit. Targeted primarily to working families with children, it acts like an earnings subsidy and seeks to increase the incomes of low-income families while providing incentives to work [9]. Among the array of federal policies that boost incomes for low-income families, the EITC is the largest and most generous [10] and it is the antipoverty program that does the most to reduce child poverty [8]. According to the IRS, the average federal credit amount is nearly $\$ 3,000$ for families with children, and $44 \%$ of families with children receive the credit [11]. The amount of the credit is determined by earnings and is structured with a phase-in earnings range in which the marginal tax rate is negative (so that with each additional dollar earned there is a subsidy in the form of a refundable tax credit), a plateau range in which the marginal tax rate is zero, and phase-out range in which the marginal tax rate is 21 percent (each additional dollar earned nets only 79 cents). For families with two children earning less than $\$ 15,000$, for example, an additional dollar of 
earned income results in a refundable tax credit (income subsidy) of $\$ .40$. Since many families in the lowest-income groups have no income tax liability, the refundable tax credit is received in its entirety as a lump-sum payment. The S1 Appendix shows how the EITC varies as household earnings increase for households of different structures.

\section{Impacts of the EITC: What the literature says}

Many have sought to understand the impacts of the EITC. Studies have focused on the economic impacts on labor supply, employment and income, as well as family functioning and child health and well-being [12,13]. In their review of studies of the EITC, Nichols and Rothstein [8] summarized the labor supply effects of the EITC: "There is an overwhelming consensus in the literature that the EITC raises single mothers' labor force participation. There is also evidence of a negative, but smaller, effect on the employment of married women, who may take advantage of the credit to stay at home with their children. There is little evidence of any effects on men, and estimated effects on the number of weeks or hours that women work, conditional on participating at all, are much smaller than those on participation” (p. 140). In their assessment of the poverty-reducing impact of the refundable tax credits, Renwick and Fox [1] using 2015 data suggested that, without the refundable tax credits such as the EITC and child tax credit, the SPMbased poverty rate would be 2.9 percentage points higher, and the child poverty rate would be 6.5 percentage points higher. This implies that refundable tax credits lift over 4.8 million children above poverty. Importantly, this effect size is a static calculation that only considers the amount of the credit without considering any work-inducing effects of the credit or changes in eligibility and participation in other public assistance programs.

Other studies have examined the impact of the EITC on educational and health outcomes of children. Dahl \& Lochner [14] found that a \$1,000 increase in income via the EITC was 
associated with an increase in math and reading test scores of children, with even larger benefits to more disadvantaged children (with low-education, unmarried caregivers). And, federal and state EITC receipt has been associated with improved maternal and child health $[15,16]$.

As noted above, there are static and dynamic effects of the EITC on employment, income and poverty. Hoynes and Patel [17] noted that the EITC can affect the income of households through three channels, generating static and dynamic effects: (1) a "credit effect," the static effect equal to the amount of the tax credit; (2) an "earnings effect," accounting for the dynamic changes in earnings induced by the EITC tax rate structure; and (3) an "income adjustment effect” that takes into account the changes in eligibility and participation in public assistance programs caused by EITC-induced changes in income. They examined these effects of the EITC on single mothers, who account for the bulk of EITC expenditures. Using both quasiexperimental difference-in-differences and event study strategies, they found that single mother employment is quite responsive to the policy-induced increases in the EITC: the elasticities of employment (extensive margin) with respect to increases in the EITC range from .31 to .46 and were consistent with prior research and across different research strategies. An additional policyinduced \$1,000 in EITC payments was associated with a 7.3 percentage point increase in employment for single mothers. Hoynes and Patel [18] also used the same two research strategies to estimate the impact of the EITC on single-mother after-tax-and-transfer (ATT) income and the probability of experiencing poverty, an analysis that accounted for the behavioral responses to the EITC. Their estimates suggest that the increases in EITC due to the 1993 expansion of the credit led to a 7.9 percentage point increase in the share of single mothers whose ATT income was above the poverty line. When both the direct and indirect effects of the EITC are accounted for, Hoynes and Patel [18] concluded the static estimates of the impact of 
the EITC on the number of poor children in single-mother families may underestimate the poverty-reducing impact of the EITC by up to 50 percent. They note that for married couples, the estimates of the response of labor supply to the EITC are zero or small and negative, and the estimate of the static effect may more closely capture the total effect of the EITC.

Recent research has also estimated the long run effects of exposure to a more generous EITC during the first two decades of adulthood. Neumark and Shirley [19] found some evidence that for unmarried women with preschool children, a more generous credit led to higher earnings and hours in later years, but for married women with young children it led to fewer hours and lower earnings in the longer run. Federal EITC expansion has also been shown to increase the likelihood of household savings and the amount held in savings balances, suggesting that the EITC contributes to financial stability among low-income families [20]. And, recent estimates suggest the EITC is a particularly cost-effective policy because the work incentives means more people are paying taxes and fewer people are relying on safety net programs [21].

\section{State EITCs and the Oregon Context}

A major long-term trend in the US social welfare system has been the devolution from Federal to State responsibility for health and welfare programs. The result has been wide crossstate variability in the structure of social welfare systems. State to state variation in welfare state characteristics is now greater than across many countries [22]. And, the inequality-reducing effects of state tax systems vary considerably [23]. State EITCs are a prime example of state-tostate variation in economic support for families. To supplement the Federal EITC, 29 states, the District of Columbia, Guam and Puerto Rico implement additional EITC-like policies. Across jurisdictions, state EITC policies vary widely in their refundability and amounts. The most common state EITC policy provides families a percentage of the Federal EITC. For example, the 
state EITC for Hawaii is 20\%. A family receiving \$3,000 from the Federal EITC would thus receive an additional \$600 from the state. State percentages of the Federal EITC range from 3\% (Montana) to 40\% (District of Columbia) [24].

\section{The Oregon Context}

A combination of socio-economic, labor, policy and other factors interact to influence how the poverty rate changes over time. Oregon has lower-than-average median household incomes (97\% of US median household income) [25]. Sectors characterized by low wages and unstable schedules such as sales, food preparation, services, and health care support are the fastest growing jobs in the state [26]. A combination of low-wage work and high child care prices put additional pressure on working families. In Multnomah County (contains Portland), $71 \%$ of a minimum wage worker's annual earnings would be needed to pay the price of center child care for a toddler [27]. And, socio-economic inequalities among children are widening. For example, the gap between poor and non-poor Oregon children on reading and math achievement from 2003 to 2013 increased at the fastest rate in the nation [28]. Further, large disparities in behavioral regulation and kindergarten assessment scores have been observed for Oregon’s lowincome students who are English language learners [29,30]. And low-income Oregon children are at high risk of food insecurity and obesity, especially in rural areas [31].

On the other hand, the state has a tradition of relatively generous social welfare and antipoverty policies that seek to offset market income poverty. Oregon’s Governor recently released a Children's Agenda which includes eight policy strategies to reduce child poverty and promote family stability [32]. In contrast to the path many states have followed, TANF in Oregon is reaching a relatively high proportion of people: $43 \%$ of the poor receive TANF compared to only 22\% nationally [33]. Among other reasons, this can be explained by longer periods of eligibility 
(up to 60 months compared to 24 months in many states). Oregon's policy response to food insecurity is considered generous, despite (or perhaps due to) relatively high levels of food insecurity [34]. Oregon exhibits high SNAP participation [35], strong agency and nonprofit collaboration, and the state made deliberate efforts to increase SNAP caseloads during the Recession in response to the increased need [36]. In 2016, Oregon passed a minimum wage increase that will see the hourly wage increase from $\$ 9.25$ to $\$ 14.75$ in 2022. (Although, early evidence from the Seattle Minimum Wage study shows potential adverse employment effects when the minimum wage increase is implemented quickly [37-39]. Last, the Working Family Household and Dependent Care Credit (WFHDC) helps low- to moderate-income families pay for the care of their dependents while they're working or looking for work [40]. Together, this confluence of market forces and policy responses make Oregon an interesting case example for the study of anti-poverty policy.

\section{Oregon Earned Income Credit}

Among states, the Oregon Earned Income Credit (OEIC) is unique because it targets early childhood poverty. The OEIC was first enacted in 1997 and was made refundable in 2006. The OEIC amount is a percentage of the federal EITC and this rate has grown from 5\% in 1997 to $6 \%$ in 2008 to $8 \%$ in 2013. And then in 2016, the Oregon Legislature increased the OEIC for families with children younger than 3 years of age, adding an additional 3\% to bring the credit for these families up to $11 \%$ of the federal EITC.

What was the rationale for the policy focus on early childhood poverty? In 2015, the Family Impact Seminar had focused on two-generation approaches to fighting poverty [41,42], and had brought two national child development experts to Oregon to discuss strategies for reducing poverty. A key theme emerging from that body of scholarship is that timing of 
economic resources - or lack thereof - appears to matter greatly for children. The negative influence of poverty begins in the prenatal period, extends and compounds across the life course. For example, up to $70 \%$ of the inequalities observed in adolescence were present when children entered school $[43,44]$. Further, a nonlinear relationship between age and income has been observed across a host of developmental outcomes. For example, Duncan and colleagues [4] showed that a \$3,000 boost to household income was related to 1/5 standard deviation increase in achievement among 4-7 year-olds but not for similar 8-13 year-olds. As childcare costs are highest in the early years, families with young children are expected to benefit more from additional cash resources.

Based largely on conversations with researchers about the potential benefits of early childhood investments, the 2016 Oregon state legislature passed HB 4110 that added an additional 3\% to the $8 \%$ of the Federal EITC, but exclusively for households with children under 3 years of age. The current OEIC - effective in the 2017 tax year - provides $11 \%$ of the federal EITC amount to qualifying families with young children ( $<3$ years old) and a credit of $8 \%$ of the federal EITC for all other qualifying families.

\section{Research questions}

The impact of the OEIC on child poverty is unknown. In addition to the implications for child development, the OEIC may have societal benefits relative to a flat rate state EITC policy for all families (as found in most other states). The current study is an attempt to explore how much the OEIC affects child poverty in the state of Oregon. The purpose is to understand how Oregon's unique early childhood-focused state EITC relates to child poverty and early child poverty. The following questions motivate the study:

1. How much is child poverty reduced with the Oregon EIC? 
2. How much is early child poverty reduced with the Oregon EIC?

3. How does the OEIC impact on child poverty vary across the low-income distribution?

4. What is the impact of the OEIC on the depth and severity of child poverty?

5. How would the child poverty rates change with more generous versions of OEIC policy?

\section{Materials and Methods}

\section{Primary data source: Current Population Survey Annual Social and Economic Supplement}

Our primary dataset was a 3-year pooled sample of Oregonians surveyed in the 2015, 2016, and 2017 Current Population Survey’s (CPS) Annual Social and Economic Supplement (ASEC) available at Integrated Public Use Microdata (IPUMS) USA [45]. CPS survey years report data for the years prior. Therefore the analysis refers to income and poverty in years 2014, 2015, and 2016. The CPS sample size for Oregon was 8,140 persons in 2,897 SPM-defined family units. The ASEC excludes any individuals who are in the military and do not live with at least one civilian adult.

\section{Measurement}

\section{Poverty}

We used the Census Bureau’s Supplemental Poverty Measure (SPM) to define poverty. Introduced in 2009, the SPM has several differences from the Official Poverty Measure (OPM). The most important differences included how families are defined, inclusion of various noncash transfer and tax credits as resources, subtracting tax payments and medical and work expenses from resources, and regional adjustments to the SPM thresholds for cost of living. The inclusion of tax credits into the bundle of household resources is necessary for this study on the impact of the OEIC on child poverty (See S2 Appendix for further detail on differences between the SPM and OPM). 


\section{Poverty unit/family unit}

We followed the Census Bureau definition of SPM family unit and use the terms family and household interchangeably. Importantly, the SPM definition incorporates co-resident unrelated children, foster children, and unmarried partners and their relatives [46]. The SPM

deviates from the Census Bureau definition of "primary families" as groups of persons related to the head of household, and "primary individuals" as household heads/householders residing without kin.

\section{Resources}

Four measures of income were used in the analysis. All values were summed by SPM family unit. Total SPM resources, a measure estimated by Census Bureau, included the sum of market income, cash transfer programs, SNAP, the Earned Income Tax Credit, Child Tax Credit and Oregon tax credits. To better capture disposable income, the total SPM resource measure also subtracts from these resources State and Federal taxes along with medical and out- ofpocket expenses, work-related expenses such as child care and transportation costs, and child support payments [47]. Information on Federal and state taxes was not collected directly in the CPS ASEC. Both are modeled by the Census Bureau’s internal tax model and included as variables in the IPUMS version of the ASEC. (For in-depth detail on how the SPM is constructed see Fox [46], and for a comparison of tax models and their implications for the SPM, see Wheaton and Stevens [48]. We used four measures in our analysis. The first measure - market income - was defined as earnings from wages and salary, business and farm income, plus rent, interest, dividends, and private pensions. This measure was used as to generate groups based on the ratio of market-income-to-need, with need represented by the SPM poverty threshold. To understand the role of the EITC and OEIC we created a second measure of family resources: 
total SPM resources minus the federal EITC and the Oregon Earned Income Credit (SPM(EITC+OEIC)). The third income measure adds the EITC back to the second measure (SPMOEIC), which allows us to see the impact of the EITC alone and without the OEIC. Finally, a comparison of the third measure with the total SPM resources (SPM) allows us to see the isolated impact of OEIC on SPM poverty.

\section{The Oregon Earned Income Credit}

The first step in estimating the OEIC was differentiating between families with young children under age 3 and families with children of all ages (i.e., under 18). We estimated the OEIC by multiplying the federal EITC by $11 \%$ for families with young children and $8 \%$ for all other families (with and without children). As others have done [49], we assumed that all eligible tax units claim the EITC (and thus OEIC).

\section{Poverty measures}

Following standard procedures, a household was considered poor if its observed resources fell below the SPM poverty threshold. SPM thresholds were provided by the Census in the public use files. Headcount child poverty rates were calculated across the four income resource measures described above (market income; SPM-(EITC+OEIC); SPM-OEIC, and SPM).

Focusing solely on the headcount poverty rate leads to an incomplete accounting of the poverty condition [50]. For example, Jolliffe et al. [51] demonstrated the utility of using the FGT poverty indices for estimating the impact of food stamp policy on child poverty. To complement the headcount poverty rates, we extended the analysis to include measures of the depth of poverty and severity of poverty. To measure poverty depth and severity, we calculated the poverty gap and squared poverty gap, respectively, as articulated by the Foster-Greer-Thorbecke 
(FGT) school of poverty indices [52]. The poverty gap, or FGT1, estimates the depth of poverty by estimating the average distance from the poverty threshold across all households in poverty. Higher gaps equate to greater average distance below the poverty threshold. Last, we also examined poverty severity with the squared poverty gap index. This measure averages the square of the poverty gap, and therefore places greater emphasis on units who are farther from the poverty threshold. The FGT poverty indices can be expressed by the following:

$$
\text { (1) } P_{\alpha}=1 / n \sum_{i} I\left(y_{i}<z\right)\left[\left(z-y_{i}\right) / z\right]^{\alpha}
$$

where $n$ is the sample size, $I$ represents household or individual, and $z$ is the poverty line. $y$ is the income measure of interest: market income; (SPM-(EITC+OEIC)); (SPM-OEIC)); and, SPM. I translates into a function that equals a value of one if the statement is true and zero if the function is false. By definition, when $\alpha=0$, the equation results in the headcount poverty rate. When $\alpha=1$ the result is the poverty gap; $\alpha=2$ equates to the squared poverty gap. Extending equation (1) to estimate the poverty indices for the OEIC $P$ ', we have the following:

$$
\text { (2) } P_{\alpha}^{\prime}=1 / n \sum_{i} I\left(\left\{y_{i}+E_{I T C}+O E I C_{i}<z\right)\left[\left(z-y_{i}\right) / z\right]^{\alpha}\right.
$$

where EITC $_{i}$ is the value of the EITC and $\mathrm{OEIC}_{i}$ is the value of the OEIC for the household. The remainder of the equation is unchanged from (1).

\section{Demographics}

Our analysis focused on children, defined as individuals under 18 years of age. The key demographic variable for understanding the OEIC impact was presence of children under age 3. A number of additional measures were included to aid in understanding how poverty was distributed across the population. Variables included employment status of the household head (at least 1 full-time/full-year worker, no full-time/full-year worker), education of the household head (college or more, some college, high school, less than high school), family structure 
(single, no children; cohabitating, no children; married, no children; single with children; cohabitating with children; married with children), gender of household head, citizenship status (foreign-born, native born), and ethnicity (other, Asian, Hispanic, black). Characteristics of the person identified in the CPS as the head of household were reported.

\section{Analysis}

The first step in the analysis was to estimate headcount poverty rates for the overall population as a reference point, while maintaining focus on poverty rates for all children, and for young children. Following the guidelines by IPUMS, individual ASEC survey weights were applied for estimating child poverty. Following procedures outlined by Rainwater et al. [53] we generated a new pooled weight that was equal to each year weight divided by three to account for the three years of pooled data. Headcount rates were calculated across the four poverty measures previously introduced. The analysis centers on a counterfactual framework where we ask: what would the hypothetical child poverty rate be if alternative resources were included? We then compare how the child poverty rate is different across the various poverty measures described above. For example, what is the poverty rate without the OEIC and with the OEIC? The terms impact used in the Results refer to the observed differences with and without the policy. Our goal is not to estimate the cause-effect relationship between the OEIC and child poverty. Rather, we use a static analysis (meaning that we assume no behavioral responses would take place in the absence of the policy) to estimate how resources would be different in absence of the policy. We acknowledge that, as others have shown, behavioral responses to the policy change are likely. However, our descriptive approach provides useful starting point for understanding the range of potential outcomes that could be expected as a result of the OEIC. The static approach has a long tradition in research on poverty and social policy $[17,54,55]$. Tests 
of statistical significance were conducted across different poverty measures $(p<.05)$, along with 95\% confidence intervals. After establishing a baseline impact of the OEIC on child poverty, we simulated alternative OEIC amounts as described above. Headcount poverty rates and confidence intervals were estimated for all children and young children. Tests of statistically significant difference were calculated for the proportional declines in these poverty rates relative to the poverty rates under current OEIC policy (11\% for families with young children; $8 \%$ for all others).

As previous research has demonstrated, the social safety net has shifted over time, with more support for working families and those closer to the poverty thresholds [56,57]. Motivated to explore how the OEIC affects poverty rates across the income distribution, we estimated a market income-to-needs ratio for market income to SPM threshold. We then coded this ratio into four groups: (1) families with market income at 0 to 50\% of the SPM threshold (this group sometimes referred to as deep poverty), (2) market incomes between 51 and 100\% of the SPM threshold, (3) market incomes at 101 to $150 \%$, and (4) market incomes at 151\% or higher. Headcount poverty rates were estimated assuming the current OEIC policy across three income measures: SPM-(EITC+OEIC), SPM-OEIC, and SPM. The final analysis estimated the three poverty indices (headcount, gap, squared gap) across the distributional groups. Because the early childhood portion of the OEIC did not affect families until the 2017 tax year, the current study is hypothetical in that we estimate the impact of the OEIC as if it had been in effect during the time of the survey data collection in calendar years 2014, 2015, 2016. ${ }^{1}$

\footnotetext{
1 Replication files available at Rothwell DW, Giordono L. The Oregon Earned Income Credit's Impact on Child Poverty [Internet]. OSF; 13 Feb 2019. Available: osf.io/hbt28
} 


\section{Results and Discussion}

Over one third of Oregon families with children are eligible for the EITC and OEIC.

Table 1 shows the shares of families, families with children, and families with young children in our sample expected to be receiving the EITC/OEIC. (As noted above, our estimates assign EITC/OEIC to all eligible families. Family is defined by SPM family unit.) Of over 487,000 families with children in Oregon, we find that about 36\% can claim the EITC/OEIC, suggesting that about 177,000 families with children are able to gain additional economic resources via this policy. And 44 percent of families with young children can get the EITC/OEIC. As expected, the demographic profile of OEIC recipients align with well-known poverty risk factors. Compared to overall families with children and young children, OEIC-receiving families had much lower education. OEIC recipients were also less likely to be married with a spouse present and identify as a US citizen. 
Table 1: Demographic Characteristics of Oregon Families with Children and Eligibility for Tax Credits, 2015-2017

\begin{tabular}{|c|c|c|c|c|c|}
\hline & $\begin{array}{l}\text { All } \\
\text { Households } \\
(\mathrm{n}=3250)\end{array}$ & $\begin{array}{l}\text { Families } \\
\text { with } \\
\text { children } \\
(\mathrm{n}=1207)\end{array}$ & $\begin{array}{c}\text { Families } \\
\text { with } \\
\text { children } \\
\text { EITC/OEIC } \\
(\mathrm{n}=436)\end{array}$ & $\begin{array}{c}\text { Families } \\
\text { with young } \\
\text { children } \\
\text { age <3 } \\
(\mathrm{n}=267)\end{array}$ & $\begin{array}{c}\text { Families } \\
\text { with young } \\
\text { children } \\
\text { age }<3 \\
\text { EITC/OEIC } \\
(\mathrm{n}=114)\end{array}$ \\
\hline & $\begin{array}{c}\text { (1) } \\
\text { Percent }\end{array}$ & $\begin{array}{c}(2) \\
\text { Percent }\end{array}$ & $\begin{array}{c}\text { (3) } \\
\text { Percent }\end{array}$ & $\begin{array}{c}\text { (4) } \\
\text { Percent }\end{array}$ & $\begin{array}{c}\text { (5) } \\
\text { Percent }\end{array}$ \\
\hline $\begin{array}{l}\text { Eligible for } \\
\text { EITC/OEIC }\end{array}$ & 15 & 36 & 100 & 44 & 100 \\
\hline Employed & 57 & 73 & 71 & 66 & 61 \\
\hline $\begin{array}{l}\text { 4-year college } \\
\text { degree }\end{array}$ & 21 & 22 & 8 & 27 & 10 \\
\hline $\begin{array}{l}\text { Married spouse } \\
\text { present }\end{array}$ & 46 & 67 & 50 & 71 & 53 \\
\hline Female head & 48 & 52 & 60 & 56 & 66 \\
\hline Not a citizen & 7 & 12 & 23 & 10 & 17 \\
\hline White & 90 & 87 & 87 & 86 & 86 \\
\hline \multicolumn{6}{|c|}{$\begin{array}{l}\text { Note. Values represent percentages with the application of household weights. As a result, } \\
\text { calculations with unweighted cell sizes may not match. } \\
\text { Demographic values are based on the person identified in the CPS as head of household. }\end{array}$} \\
\hline
\end{tabular}

\section{Impact of EITC and OEIC on Child Poverty and Young Child Poverty}

To address the first two research questions, we estimated a series of poverty rates that indicate the extent to which the SPM resources and adjustments, and particularly the earned income tax credits, reduced the rate of child poverty below what it would be based only on market income (see Table 2). When only market income is considered as resources, about one in five Oregon children (20.15 percent) were poor. Considering all SPM resources (adding cash and noncash transfers and subtracting medical and work expenses and taxes) except the EITC and OEIC reduced the child poverty rate to 18.14 percent. By comparing columns (2) and (3) we can see that the Federal EITC had a substantial impact on child poverty in Oregon, reducing the SPM 
child poverty rate to 13.55 percent, a 25 percent proportional reduction. This lifted about 41,000 of the approximately 161,000 Oregon poor children out of poverty. These results are consistent with prior research on the Federal EITC. By contrast, our results reported in columns 3 and 4 suggest that the OEIC - at its current level - did not reduce child poverty in Oregon at all. Though young children in Oregon are about as vulnerable to market income and SPM poverty as all children, the EITC does not yield as large an impact for young children. The EITC reduced the SPM poverty rate for young children by 18 percent from 19.63 percent to 16.13 percent, lifting about 4,800 young children above the SPM threshold. Yet after the EITC, young children were ultimately left at greater risk of SPM poverty (poverty rate $=16.13$ percent) than the population overall (13.00 percent) and all children aged 18 and under (13.55 percent). 
Table 2: Poverty rates in Oregon 2015-2017 with and without earned income tax credits

\begin{tabular}{|c|c|c|c|c|}
\hline & $\begin{array}{c}\text { Market Income } \\
{[95 \% \mathrm{CI}]} \\
\text { (1) }\end{array}$ & $\begin{array}{c}\mathrm{SPM}-(\mathrm{EITC}+\mathrm{OEIC}) \\
{[95 \% \mathrm{CI}]} \\
(2)\end{array}$ & $\begin{array}{c}\text { SPM - OEIC } \\
{[95 \% \mathrm{CI}]} \\
(3)\end{array}$ & $\begin{array}{c}\text { SPM } \\
{[95 \% \mathrm{CI}]} \\
(4)\end{array}$ \\
\hline Overall population & $\begin{array}{c}21.90^{* * *} \\
{[20.92,22.88]}\end{array}$ & $\begin{array}{c}15.00^{* * *} \\
{[14.18,15.82]}\end{array}$ & $\begin{array}{c}13.00 \\
{[12.21,13.78]}\end{array}$ & $\begin{array}{c}13.00 \\
{[12.21,13.78]}\end{array}$ \\
\hline $\begin{array}{l}\text { All children } \\
(\text { age }<18)\end{array}$ & $\begin{array}{c}20.15^{* * *} \\
{[18.42,21.88]}\end{array}$ & $\begin{array}{c}18.14^{* * *} \\
{[16.48,19.81]}\end{array}$ & $\begin{array}{c}13.55 \\
{[12.06,15.04]}\end{array}$ & $\begin{array}{c}13.55 \\
{[12.06,15.04]}\end{array}$ \\
\hline $\begin{array}{l}\text { Young children } \\
(\text { age }<3)\end{array}$ & $\begin{array}{c}19.99^{* * *} \\
{[15.32,24.66]}\end{array}$ & $\begin{array}{c}19.63^{* * *} \\
{[14.98,24.28]}\end{array}$ & $\begin{array}{c}16.13 \\
{[11.81,20.44]}\end{array}$ & $\begin{array}{c}16.13 \\
{[11.81,20.44]}\end{array}$ \\
\hline \multicolumn{5}{|c|}{$\begin{array}{l}\text { Note. Statistical significance tests performed for children against SPM rate: } * * * p<.001 ; * * p<.01 ; * p<.05 \text {. } \\
\text { Values represent poverty rates. Column } 1 \text { is poverty rate based on market income. } \\
\text { SPM - (EITC+OEIC) = poverty rate in the absence of both EITC and OEIC } \\
\text { SPM - OEIC = poverty rate in the absence of the OEIC (but including the EITC) } \\
\text { SPM = poverty rate including both the EITC and OEIC } \\
\text { Data source is Current Population Survey 2015, 2016, } 2017 \text {. }\end{array}$} \\
\hline
\end{tabular}


As was the case for all children, the OEIC did not reduce poverty for young Oregon children. In this combined CPS sample there were no young children that were raised out of SPM poverty by the OEIC (rate of 16.13 percent for both columns 3 and 4).

The OEIC's null effect on child poverty may be explained by a combination of level of the EITC amount and income profiles of families with children pre-OEIC. Table 3 shows that, although the average estimated Federal EITC was about $\$ 3060$ for families with children in Oregon, the estimated OEIC was only $\$ 273$. Furthermore, the compositional reality was that poor families with children had incomes too far from the poverty threshold to be affected by the small amount of OEIC.

\begin{tabular}{|c|c|c|c|}
\hline \multicolumn{4}{|c|}{$\begin{array}{l}\text { Table 3: EITC and OEIC for Oregon families with Children by Market- } \\
\text { Income-to-Need Group, 2015-2017 }\end{array}$} \\
\hline & $\begin{array}{l}\text { Percent of } \\
\text { Families with } \\
\text { Children Eligible } \\
\text { for EITC }\end{array}$ & $\begin{array}{c}\text { Average } \\
\text { Estimated } \\
\text { Federal EITC } \\
\text { Amount in } \\
\text { USD }\end{array}$ & $\begin{array}{l}\text { Average } \\
\text { Estimated } \\
\text { Oregon } \\
\text { EIC in USD }\end{array}$ \\
\hline $\begin{array}{l}\text { Market-Income- } \\
\text { To-Need Group }\end{array}$ & (1) & $(2)$ & (3) \\
\hline Overall & 36 & 3060 & 273 \\
\hline $\begin{array}{l}\text { 0-.50 MI/ } \\
\text { SPMthresh }\end{array}$ & 43 & 2340 & 218 \\
\hline $\begin{array}{l}.51-1.00 \mathrm{MI} / \\
\text { SPMthresh }\end{array}$ & 93 & 4762 & 422 \\
\hline $\begin{array}{l}1.01-1.50 \mathrm{MI} / \\
\text { SPMthresh }\end{array}$ & 93 & 3419 & 301 \\
\hline $\begin{array}{l}1.51 \mathrm{MI} / \mathrm{SPMthresh} \\
\text { and greater }\end{array}$ & 20 & 2042 & 185 \\
\hline \multicolumn{4}{|c|}{$\begin{array}{l}\text { Note. In columns (2) and (3), reported values are conditional on credit receipt. } \\
\text { Weights are applied at household level using spmweight. } \\
\text { Data source is Current Population Survey 2015, 2016, } 2017 .\end{array}$} \\
\hline
\end{tabular}


Such variation is to be expected, of course, as the amount of the tax credit for any family depends in part on the level of earned income, with credit amounts increasing as family earnings increase toward the poverty threshold and decreasing after a point as families earn more and move out of poverty. Table 3 also shows that average amounts of EITC/OEIC are quite modest (\$218) for those with the lowest market incomes. The average amounts received among families at 0 to $50 \%$ of the MI/SPM were about one-half of those at 51 to $100 \%$ of the MI/SPM. The average EITC/OEIC amounts are largest for families with market incomes between $51 \%$ and $100 \%$ of the SPM threshold and the program provides significant tax credits to those with incomes substantially above the poverty line.

\section{Effect of EITC/OEIC on Child Poverty by Market-Income-to-Need Group}

Table 4 shows the SPM poverty rates without the EITC or OEIC for all children (Column1) and young children (Column 4) across four market income-to-needs groups. The impact of the EITC alone is seen by comparing Columns 1 and 2 for all children and Columns 4 and 5 for young children, and the impact of the adding the OEIC to the EITC is seen by comparing Columns 2 and 3 for all children and Columns 5 and 6 for young children. The results in the "overall" row are taken from the lower right-hand section of Table 2 and are repeated here to provide a reference point for the results for each market-income-to-need group. 
Table 4: Estimated Child Poverty Rates for Oregon Families with Children by Market-Income-to-Need Group and Age Group, with and without Tax Credits

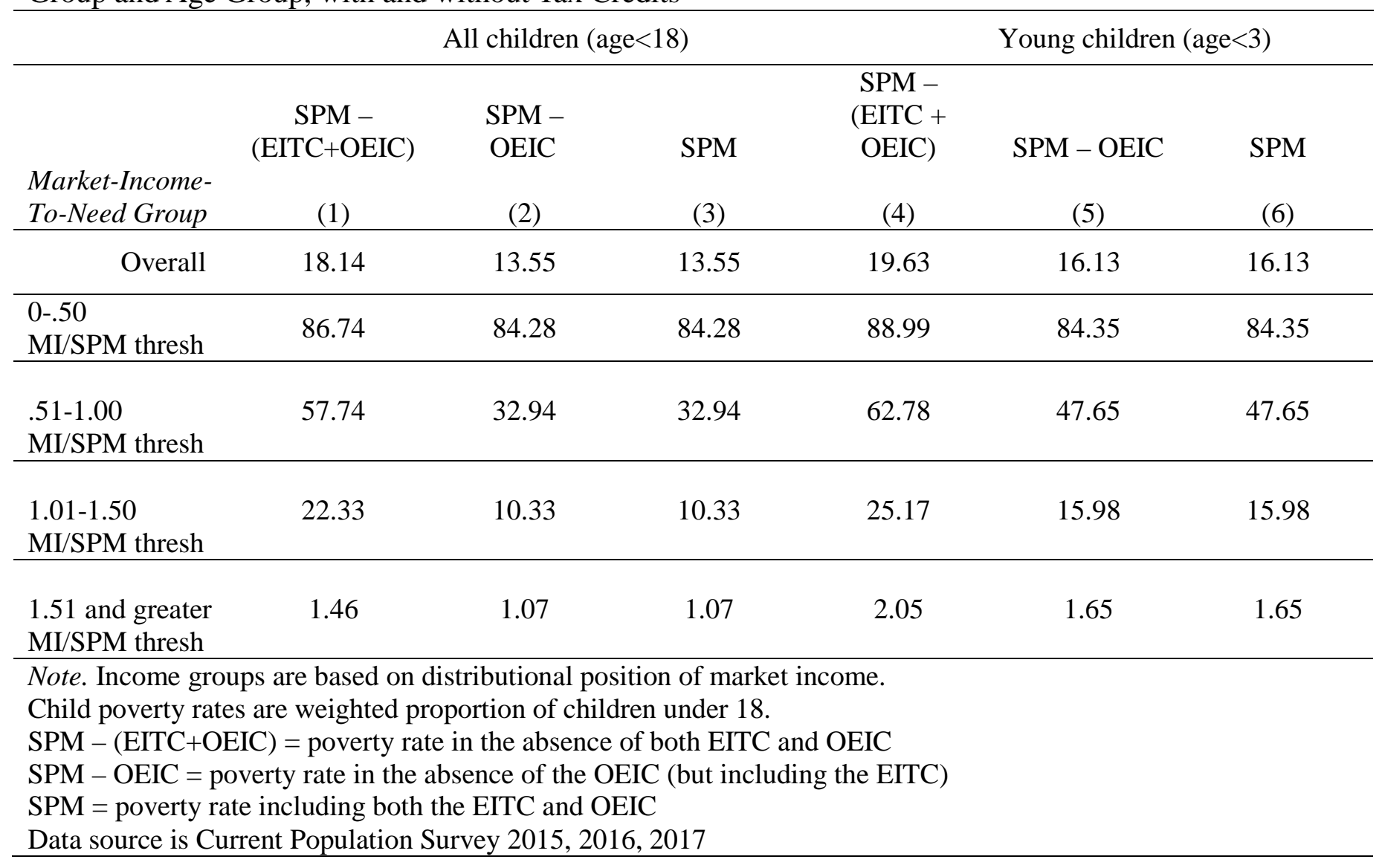


There are two important things to note about the results in Table 4. First of all, the EITC's impact on poverty is considerable, but primarily for families just above and below the SPM poverty threshold. For example, the poverty rate for young children between $51-100 \%$ of MI/SPM without the EITC was about $63 \%$. When the EITC was considered, the poverty rate fell by about 15 pp (a $24 \%$ proportional decline). In comparison, the poverty rate of young children in deep poverty ( 0 to $50 \%$ of MI/SPM) was reduced in absolute terms with the EITC by only about 5 pp from 89 percent to 84 percent.

The distributional benefits to those between $50-100 \%$ of the MI/SPM is even greater for all children. For families at $51-100 \%$ of MI/SPM, the child poverty rate is reduced from 58 percent to 33 percent, a 25 pp (43\%) reduction. For those in deep poverty, the impact is again much smaller with the EITC reducing the child poverty rate by 3 percent (2.46 pp) from 87 percent to 84 percent.

The second thing to note is that the estimated impacts are due entirely to the EITC and not to the OEIC. The poverty rates for the SPM without and with the OEIC (shown in columns 2 and 3 for all children and columns 5 and 6 for young children) are identical, indicating that the OEIC does not move children or young children above the poverty threshold at any market income level.

Kernel density plots provide additional insight into how the public safety net and tax system changes the resources available to Oregon families with children across resource to SPM threshold ratios for all four resource measures. Figs 1a and 1b show the estimated probability density functions for all families with children by the ratio of income/resources relative to the SPM threshold for the four different resource measures. Fig 1a shows the kernel density for families with a ratio of resources to SPM threshold from 0 to 8 , which captures almost the entire 
distribution of families with children, while Fig 1b zooms in on families with resource to SPM threshold ratios of less than 1.5. In both figures, the dashed vertical line at the 1.0 ratio separates the poor to the left of the line from the non-poor to the right of the line.

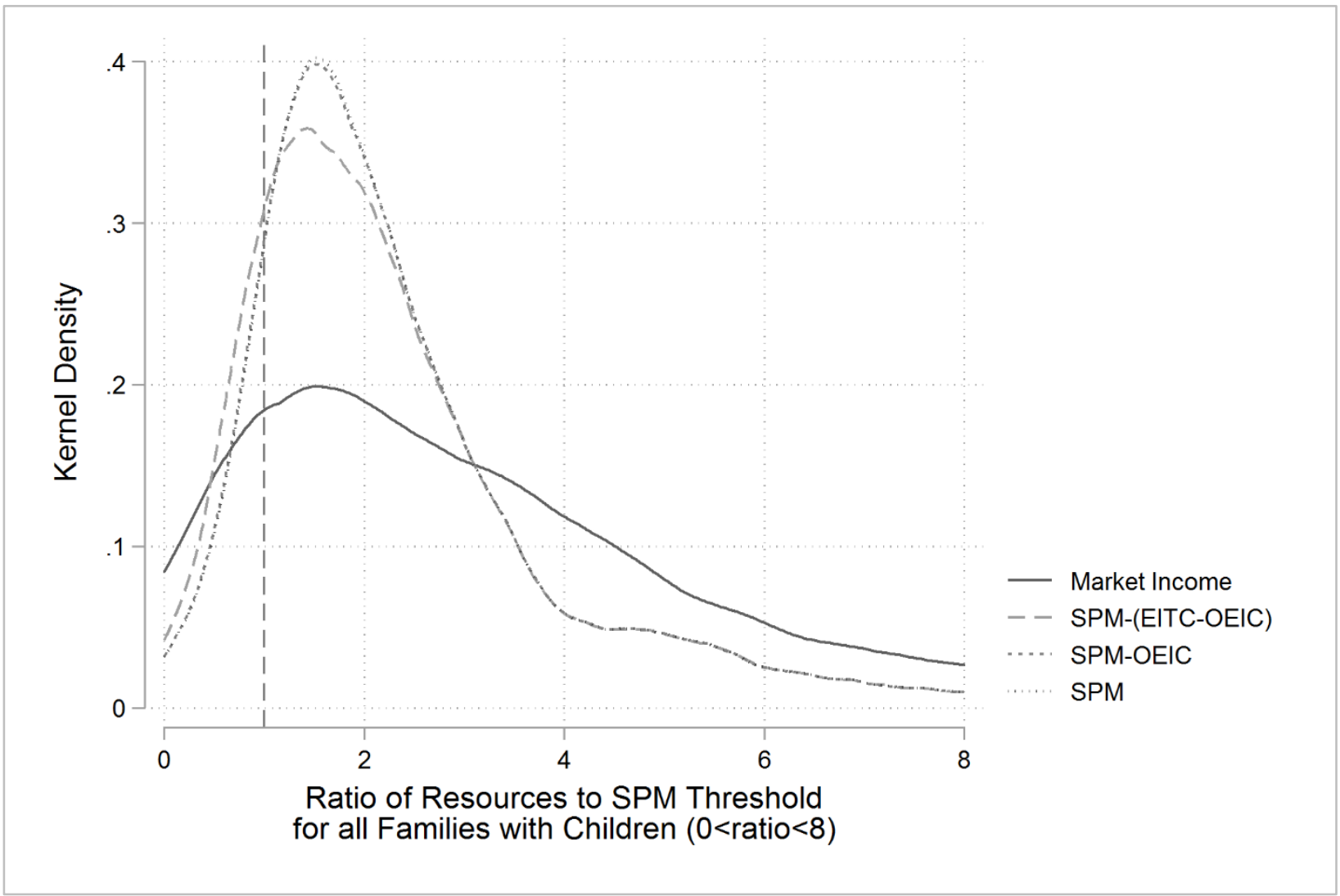

Fig 1a. Kernel Density Plot of Ratio of Resources to SPM Threshold across the Distribution (0 to 8) 




Fig 1b. Kernel Density Plot of Ratio of Resources to SPM Threshold across the Distribution (0 to 1.5)

At the upper end of the distribution, the fact that the market income line lies above the other three lines suggests that the tax system redirects resources to the safety net, and the fact that the other three lines essentially overlap above the resource/SPM ratio of 3 suggests that earned income tax credits have no impact at this level, as we would expect.

Fig 1b concentrates on the lower tail of these distributions showing the distributions using the four different measures across the resource/SPM ratios from 0 to 1.5 . At the bottom end of the distribution, the fact that the market income line is above the dashed SPM without tax credits line, suggests the social safety net reduces the share of families in deep SPM poverty. And the gap between the dashed line and the dotted lines below indicates that the EITC reduces the share of families with children in poverty, and that it does so more for families around the poverty line than for the poorest families. Even at this larger scale in Fig 1b, it is difficult to 
discern a difference between the SPM line and the SPM-OEIC line, suggesting that the modest resources of the program do little to shift the estimated probability of poverty. The only section of the distribution in which the OEIC appears to slightly lower the share of families in SPM poverty is for ratios between $51-100 \%$ of MI/SPM.

\section{Impact of OEIC on Rate, Depth and Severity of Child Poverty}

To supplement the results on headcount poverty rates we next considered the depth and severity of child poverty. Table 5a shows how the OEIC reduced the level of child poverty (headcount poverty rate), the poverty gap (depth) and the squared poverty gap (severity) indices for all children and young children and Table 5b provides these results separately for children in deep poverty (0-50\% MI/SPM) and those in families in the 51-100\% of MI/SPM group.

\begin{tabular}{|c|c|c|c|c|c|}
\hline \multicolumn{6}{|c|}{$\begin{array}{l}\text { Table 5a: Child Poverty Level, Depth and Severity under Current Estimated OEIC, by Age } \\
\text { Group }\end{array}$} \\
\hline & $\begin{array}{l}\text { MI } \\
(1)\end{array}$ & $\begin{array}{c}\text { SPM - } \\
(\text { EITC+OEIC) } \\
(2)\end{array}$ & $\begin{array}{l}\text { SPM - OEIC } \\
\text { (3) }\end{array}$ & $\begin{array}{c}\text { SPM } \\
(4)\end{array}$ & $\begin{array}{l}\text { Prop } \Delta \\
\text { (5) }\end{array}$ \\
\hline \multicolumn{6}{|l|}{ All children (age $<18$ ) } \\
\hline Headcount rate & 20.15 & 18.15 & 13.55 & 13.55 & 0.00 \\
\hline Gap & 10.60 & 6.70 & 5.17 & 5.07 & -2.07 \\
\hline Squared gap & 8.08 & 4.32 & 3.37 & 3.30 & -1.89 \\
\hline \multicolumn{6}{|c|}{ Young children $($ age $<3)$} \\
\hline Headcount rate & 19.99 & 19.63 & 16.13 & 16.13 & 0.00 \\
\hline Gap & 9.63 & 6.88 & 4.95 & 4.76 & -3.73 \\
\hline Squared gap & 7.04 & 4.59 & 3.27 & 3.17 & -3.23 \\
\hline \multicolumn{6}{|c|}{$\begin{array}{l}\text { Note. Poverty indices are calculated as Foster-Greer-Thorbecke headcount ratio, average normalizec } \\
\text { poverty gap and average squared normalized poverty gap. Child poverty rates are weighted } \\
\text { proportion of children under } 18 . \\
\text { SPM - (EITC+OEIC) = poverty rate in the absence of both EITC and OEIC } \\
\text { SPM - OEIC = poverty rate in the absence of the OEIC (but including the EITC) } \\
\text { SPM = poverty rate including both the EITC and OEIC } \\
\text { Data source is Current Population Survey 2015, 2016, } 2017\end{array}$} \\
\hline
\end{tabular}


The first four columns of Table 5a reproduce the sequence for showing impacts in Table 2. Column 1 shows the market income poverty rate; Columns 2, 3 and 4 show the Supplemental Poverty Measure poverty rate without the EITC/OEIC, with EITC but without OEIC, and with both EITC and OEIC, respectively. The difference between columns 3 and 4 indicates how much lower the SPM is with the OEIC. The proportional change [prop $\Delta$ ] in Column 5 is calculated by subtracting the entry in column 3 from the entry in column 4 and dividing by the entry in column 3. Though the OEIC did not reduce the headcount poverty rate for all children at all (prop $\Delta=$ 0.0) the addition of the OEIC to household resources reduced the poverty gap for all children by 2.07 percent and it reduced the squared poverty gap by 1.89 percent. The reduction in the poverty gap and severity for young children was even greater, at 3.73 and 3.23 percent, respectively.

Table 5b shows that the OEIC does far less to reduce the depth, and severity of poverty for children in the lower group of the market-income-to-need distribution (0 to 50\%) compared to children whose families had market incomes between 50 and 100\% of the SPM. The headcount poverty rate was not reduced by the OEIC for either children or young children in either market-income-to-need group. For the lowest income families (i.e., with market incomes less than half the SPM poverty threshold) the OEIC reduced the poverty gap index by 0.96 percent for all children and 2.12 percent for young children. The OEIC reduced the severity of poverty even more, with a 1.06 percent reduction in the squared poverty gap index for all children in deep poverty and a 2.36 percent reduction for young children in deep poverty. 


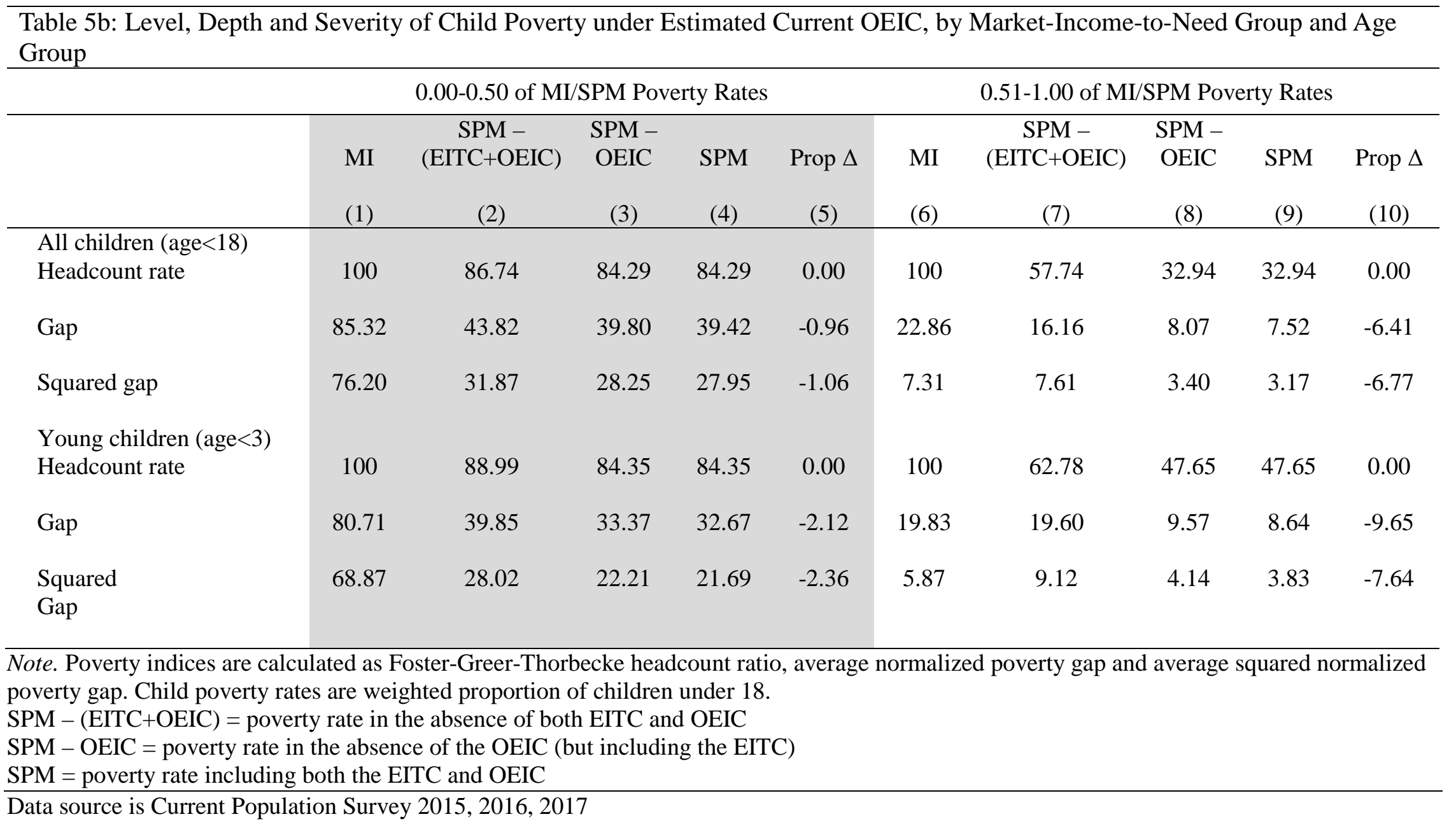


For children closer to the poverty threshold (with family market incomes between 51 and $100 \%$ of the SPM), however, the OEIC reduced the poverty gap for all children by 6.41 percent and over 9.65 percent for young children. The OEIC reduced the severity of poverty by about the same amounts, with 6.77 percent and 7.64 percent reductions in the poverty severity index for all children and young children, respectively.

\section{Impact of More Generous OEIC on Child Poverty and Young Child Poverty}

How would child poverty be affected if the OEIC were structured differently? To address our last research question, we introduced four policy options that simulate alternatives to the current OEIC (which provides a credit that is 11\% of the Federal EITC for families with young children, and $8 \%$ for all others). The first simulation increases the OEIC rate to $20 \%$ of the EITC for all children, equal to the average state-level EITC rate across states with refundable credits. Next, we double that to provide $40 \%$ for all families with children, which represents the most generous state EITC rate currently in effect. We then simulate a rate of 11 percent for families with children with an additional 18\% (a total rate of 29\%) for families with young children. This rate structure is one that provides a large enough state credit to significantly reduce both child poverty and young child poverty in Oregon. Last, we simulate a rate of 20 percent for families with children, and an additional 5\% (for a total rate of 25\%) for families with young children; this is the change that has been proposed under House Bill 3028 [58].

Each of these alternatives has a different impact on child poverty and a different cost associated with it (see Table 6 and Figure 2). In our data, the current OEIC is estimated to cost \$48.3 million, providing families with children an average OEIC of \$273. This cost is slightly more than administrative data showing that 253,000 families claimed the OEIC for Tax Year 
2016 with a cost of about $\$ 43.3$ million, an average of $\$ 171$ per claimant (Oregon Department of Revenue, 2018). In addition to uptake, discrepancies between administrative data and CPS estimates exist because of differences between family definitions. Raising the OEIC rate to average state earned income credit of 20 percent for all children would more than double the cost adding \$59.9 million to the cost while boosting the average OEIC amount to families with children to $\$ 612$. This option would reduce child poverty for all children by $0.36 \mathrm{pp}$, a 2.69 percent reduction, but would have no effect on young child poverty. 
Table 6: Child Poverty Rates under Alternative OEIC Structures

\begin{tabular}{|c|c|c|c|c|c|}
\hline & $\begin{array}{c}\text { SPM - OEIC } \\
{[95 \% \text { CI }]}\end{array}$ & $\begin{array}{c}\text { SPM } \\
{[95 \% \text { CI }]}\end{array}$ & Absolute $\Delta$ & $\begin{array}{c}\text { Proportional } \\
\Delta\end{array}$ & $\begin{array}{l}\text { Average } \\
\text { Estimated } \\
\text { OEIC per } \\
\text { Family in } \\
\text { USD }\end{array}$ \\
\hline & (1) & (2) & (3) & (4) & (5) \\
\hline \multicolumn{6}{|c|}{ Simulation 1: Increase to $20 \%$ for all children } \\
\hline $\begin{array}{l}\text { All children } \\
(\text { age }<18)\end{array}$ & $\begin{array}{c}13.55 \\
{[12.06,15.04]}\end{array}$ & $\begin{array}{c}13.18 \\
{[11.71,14.66]}\end{array}$ & $-0.36^{* *}$ & $-2.69 * *$ & 612.00 \\
\hline $\begin{array}{l}\text { Young } \\
\text { children } \\
(\text { age }<3)\end{array}$ & $\begin{array}{c}16.13 \\
{[11.81,20.44]}\end{array}$ & $\begin{array}{c}16.13 \\
{[11.81,20.44]}\end{array}$ & 0.00 & 0.00 & 662.10 \\
\hline \multicolumn{6}{|c|}{ Simulation 2: Increase $40 \%$ all children } \\
\hline $\begin{array}{l}\text { All children } \\
(\text { age }<18)\end{array}$ & $\begin{array}{c}13.55 \\
{[12.06,15.04]}\end{array}$ & $\begin{array}{c}12.15 \\
{[10.74,13.56]}\end{array}$ & $-1.40^{* * *}$ & $-10.32 * * *$ & 1224.00 \\
\hline $\begin{array}{l}\text { Young } \\
\text { children } \\
(\text { age }<3)\end{array}$ & $\begin{array}{c}16.13 \\
{[11.81,20.44]}\end{array}$ & $\begin{array}{c}13.29 \\
{[9.39,17.20]}\end{array}$ & $-2.83^{* * *}$ & $-17.58^{* *}$ & 1324.20 \\
\hline \multicolumn{6}{|c|}{ Simulation 3: Increase to $11 \%$ for families with children, $29 \%$ for families with young children } \\
\hline $\begin{array}{l}\text { All children } \\
(\text { age }<18)\end{array}$ & $\begin{array}{c}13.55 \\
{[12.06,15.04]}\end{array}$ & $\begin{array}{c}12.97 \\
{[11.51,14.43]}\end{array}$ & $-0.58^{* * *}$ & $-4.29 * * *$ & 506.63 \\
\hline $\begin{array}{l}\text { Young } \\
\text { children } \\
(\text { age }<3)\end{array}$ & $\begin{array}{c}16.13 \\
{[11.81,20.44]}\end{array}$ & $\begin{array}{c}14.68 \\
{[10.54,18.82]}\end{array}$ & $-1.45^{*}$ & $-8.98^{*}$ & 960.04 \\
\hline \multicolumn{6}{|c|}{ Simulation 4: Increase to $20 \%$ for families with children, $25 \%$ for families with young children } \\
\hline $\begin{array}{l}\text { All children } \\
(\text { age }<18)\end{array}$ & $\begin{array}{c}13.55 \\
{[12.06,15.04]}\end{array}$ & $\begin{array}{c}13.18 \\
{[11.71,14.66]}\end{array}$ & $-0.36 * *$ & $-2.69 * *$ & 659.23 \\
\hline $\begin{array}{l}\begin{array}{l}\text { Young } \\
\text { children } \\
(\text { age }<3)\end{array} \\
\end{array}$ & $\begin{array}{c}16.13 \\
{[11.81,20.44]}\end{array}$ & $\begin{array}{c}16.13 \\
{[11.81,20.44]}\end{array}$ & 0.00 & 0.00 & 827.62 \\
\hline \multicolumn{6}{|c|}{$\begin{array}{l}\text { Note. Statistical significance tests of proportional ratio: } * * * p<.001 ; * * p<.01 ; * p<.05 . \\
\text { In column 4, Proportional changes are reported in percentage points (proportional change * 100). } \\
\text { SPM - OEIC = poverty rate in the absence of the OEIC (but including the EITC) } \\
\text { SPM = poverty rate including both the EITC and OEIC } \\
\text { Data source is Current Population Survey 2015, 2016, } 2017\end{array}$} \\
\hline
\end{tabular}




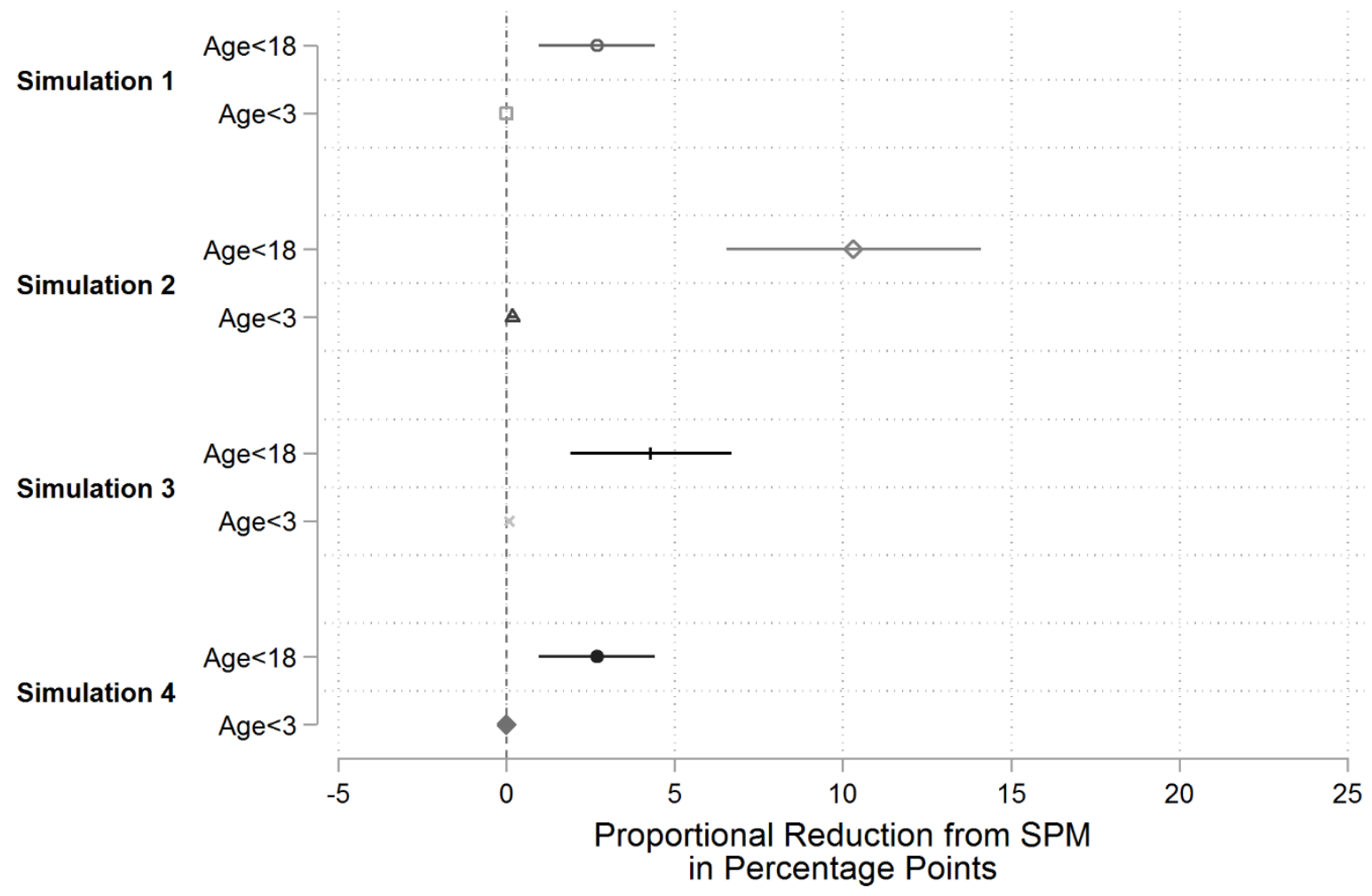

Fig 2. Proportional Reduction from SPM under Alternative OEIC Structures

An expansion of the OEIC to $40 \%$ of the Federal EITC for all children would reduce the child poverty rate by over 10 percent for all children from 13.55 percent to 12.15 percent. Importantly, this policy change would reduce the young child poverty rate by 13 percent, from 16.13 percent to 13.29 percent. Raising the OEIC to 40 percent - the highest rate among any state or jurisdiction - would almost quadruple the current cost of the program adding \$168 million to costs, while increasing the average OEIC amount to families to $\$ 1224$.

These findings suggest that it is possible to reduce child and young child poverty, but with markedly different policy structures. Through a series of simulations of different rate structures, we identified the minimum level that would reduce child and young child poverty by statistically significant amounts. This structure increased the OEIC rate applied to the Federal 
EITC to 29 percent for young children while increasing the rate for all other children to the 11 percent currently available for young children. This alternative OEIC would reduce the overall child poverty rate by 4.29 percent to a poverty rate of 12.97 , and it would reduce the young child poverty rate by 8.98 percent to 14.68 . It would also cost less than either of the previous

alternatives. This option would not quite double the cost of the program, increasing costs by only \$41.3 million, providing an average OEIC amount of \$507 per family.

Finally, we simulate the effects of the current proposal in House Bill 3028. That alternative would yield the same effects as Simulation 1 (20\% for all children), namely because the increase for young children is not sufficient to yield a positive estimated impact for that group. The average OEIC amount per family (\$659) and increase in total costs (\$68 million) would be slightly higher than those estimated for Simulation 1.

\section{Discussion}

In this study we consider how child poverty is affected by the Oregon Earned Income Credit - Oregon's supplement to the Federal EITC. The OEIC is unique among state EITC policies for the additional 3\% of the Federal EITC amount that is transferred to families with young children under the age of three. All other families in the state receive $8 \%$. The policy choice is based on evidence that young children may benefit more from additional income relative to their older peers [59]. With an average amount of $\$ 273$, our results suggest that no children are lifted above the SPM threshold with the OEIC. We also found no evidence that the OEIC's supplemental 3\% of federal EITC lifts any young children aged 2 and younger out of poverty. Our counterfactual policy changes simulated that changes to the OEIC could result in poverty rate changes that range from zero change up to a $3 \mathrm{pp}$ (17 percent) reduction in early childhood poverty for the most expansive option ( $40 \%$ of the federal EITC). For the first time, 
we identify the level of OEIC that would be needed to significantly reduce child poverty: the current $11 \%$ of federal would need to be increased to $29 \%$. It remains to be seen whether these proposals are politically or fiscally feasible.

Our results across the income distribution reveal that, for families below the poverty line, the EITC structure, and therefore OEIC structure, is regressive [60]. In addition to smaller reductions in poverty headcounts for the families in deep poverty, we find smaller proportionate reductions in the depth and severity of poverty associated with EITC and OEIC receipt are experienced by families in deep poverty. The poverty gap reduced by 1 percent and 2 percent for all children and young children, respectively, in deep poverty (i.e., with market incomes up to half the SPM poverty threshold), for example, but by it is reduced by 7 percent and 10 percent among all children and young children, respectively, in families with market incomes between 51 and 100 percent of the poverty threshold.

In light of the modest effects of the current OEIC on child poverty, and specifically the limited impact on poverty at the lower end of the distribution, other policies could be more effective at raising children out of poverty. One option would be to adjust the OEIC for geographic differences in the cost of living. Such an approach might help offset relatively higher housing costs in many of Oregon's communities. Oregon's recent minimum wage change implemented three different rates depending on location. Perhaps other state policies such as the OEIC could similarly adjust resources to high- and low-cost geographies. Scholars have recently proposed universal child benefits and allowances [61,62]. Given that states are expected to have increased latitude to shape welfare policies, it is plausible that states such as Oregon could experiment with child allowances at a state level. 


\section{Limitations}

It is important to keep in mind that our analysis assumes $100 \%$ participation for both the EITC and the OEIC, whereas some estimate the actual uptake rate in Oregon to be around 75\% [63]. This assumption explains discrepancies between our analysis based on survey data and actual estimates from administrative data [64]. However, in analyses that randomly assigned EITC uptake to $75 \%$ of those eligible yields findings that are aligned with the main findings presented here (results not shown but available upon request). It should be considered that analysis of taxes with survey data usually leads to underestimates of totals compared to IRS figures [49], and therefore our assumption may be the best way to approximate uptake with survey data.

Other limitations are noteworthy. Our analysis relies on the CPS, which has small sample sizes for some groups. It's possible that we did not detect any changes in early childhood poverty despite real changes occurring. This type II error may be attributed to sampling error in the CPS. The underreporting of major safety net programs such as SNAP and TANF are also common in most household surveys [65-68]. In Oregon, a match of CPS data to State of Oregon administrative records showed that SNAP amounts were underreported by approximately $40 \%$ [68]. Last, our estimates of impact are static and ignore potential behavioral changes that would take place if the current OEIC policy were changed. For example, the earnings effect and the income adjustment effect described by Hoynes and Patel [17] are not addressed. When factored into the total impact of the policy, these authors concluded that static estimates of the impact of EITC on single mothers may underestimate the total effect by $50 \%$. 


\section{Future Directions}

The current study leaves a number of unanswered questions. Future work will explore possibilities to correct for underreporting of benefits in the CPS. It may be possible to link the survey with administrative data via the Census Research Data Center at the University of Washington. Others have shown that combining survey with administrative data greatly changes the measured impact of social policies, especially for families in the lower parts of the income distribution [65]. The Urban Institute’s Transfer Income Model (TRIM) may be another option. The TRIM is a microsimulation model of tax, transfers, and health programs and has been used to simulate policy changes [69]. We are also in the process of requesting direct access to administrative data from the state of Oregon Department of Human Services and Employment Department. Much work remains for better understanding how OEIC participation intersects with other major safety net mechanisms, e.g., the Additional Child Tax Credit and SNAP.

The current study considered varying the amount of OEIC resources received by families. Other policy changes could be imagined. For example, keeping a targeted approach that benefits young children, resources could be phased out with declining benefits starting, perhaps, at age 5; an age-tiered structure is provided in Schaefer et al. [an age-tiered structure is provided in 62]. If the policy goal was to reduce as much poverty as possible, then a more fundamental rethinking of the redistribution might be warranted. As demonstrated with SNAP research, in theory, resources from non-poor families who receive EITC could be targeted towards the market income poor [51]. With about one-fourth of eligible families not accessing the credit, Oregon has one of the lowest participation rates in the country [63]. Increasing the uptake of the EITC is a priority of policymakers. Oregon's Governor signed into law a policy requiring employers to provide written notice to employees about state and federal earned income tax credits [70]. 
Further research is needed to better understand why such a high share of Oregonians are not participating. And, what would the impact(s) of the OEIC be if it were targeted to a different population, not necessarily anchored to the federal EITC? Unlike the OEIC, California's state EITC specifically targets the deep poor by providing up to 85 percent of the federal EITC to those with very low earnings (the California Credit phases out by household income of $\$ 15,000$ compared to the phase out limit for the Federal Credit over $\$ 40,000)$. As a result estimates suggest the California EITC reduced deep poverty by 1.4 percentage points [49]. Rueben et al. provide a comprehensive review of the California EITC model [71].

Even without such alternative structures, however, our analysis has indicated that, with higher credit levels, the OEIC has potential to reduce more child poverty in Oregon. If the OEIC were increased to 40 percent for all children, the poverty rate for all children would decrease by 10 percent and for young children by 18 percent.

But even at with its current level and rate structure, the OEIC reduces economic hardship for children living in low-income families, particularly for those with market incomes near the poverty line. Though our results suggest that the effect of adding the relatively small OEIC to household income on the headcount poverty rate was zero for all children and for young children, policymakers would reach an incorrect conclusion about the OEIC impact on child poverty if they based their evaluation on this headcount poverty impact alone. Our analysis shows that the OEIC generated substantial reductions in the depth and severity of poverty for those not in deep poverty and modest reductions for those in deep poverty. For the families with market incomes between 50 and 100 percent of the SPM poverty threshold, the current OEIC reduces both the poverty gap index and the poverty severity index by about 6 percent for all children, and reduces the poverty gap and severity by 6 and 9 percent, respectively, for young 
children. And for those families in deep poverty, the OEIC reduces poverty depth and severity by about 1 percent for all children and 2 percent for young children. 


\section{Acknowledgements}

We acknowledge the support from Monica Fisher for the ACS and TAXSIM linkage. We thank Bobbie Weber for comments on this project idea and for providing references for child care costs in Oregon and Lonnie Berger for comments on an earlier draft. We also thank Dean

Jolliffe at the World Bank for suggestions on significance testing of proportional changes and the FGT set of alternative poverty measures. 


\section{References}

1. Renwick T, Fox L. The Supplemental Poverty Measure: 2015. Washington D.C.: US Census Bureau; 2016. Report No.: P60-258.

2. Duncan GJ, Yeung WJ, Brooks-Gunn J, Smith JR. How much does childhood poverty affect the life chances of children? Am Sociol Rev. 1998;63: 406-423. doi:10.2307/2657556

3. McLoyd VC. Socioeconomic disadvantage and child development. Am Psychol. 1998;53: 185-204. doi:10.1037/0003-066X.53.2.185

4. Duncan GJ, Magnuson K, Votruba-Drzal E. Boosting family income to promote child development. Future Child. 2014;24: 99-120.

5. Duncan GJ, Magnuson K, Votruba-Drzal E. Moving beyond correlations in assessing the consequences of poverty. Annu Rev Psychol. 2017;68: 413-434. doi:10.1146/annurevpsych-010416-044224

6. Oregon State Legislature. Oregon Legislative Information System [Internet]. HB 4110 Jun 2, 2016. Available: https://olis.leg.state.or.us/liz/2016R1/Measures/Overview/HB4110

7. Bitler M, Karoly LA. Intended and unintended effects of the war on poverty: What research tells us and implications for policy. J Policy Anal Manage. 2015;34: 639-696.

8. Nichols A, Rothstein J. The Earned Income Tax Credit. In: Moffitt R, editor. Economics of Means-Tested Transfer Programs in the United States. Chicago: University of Chicago Press; 2016. pp. 137-218.

9. Bitler M, Hoynes H. The more things change, the more they stay the same? The safety net and poverty in the Great Recession. J Labor Econ. 2016;34: S403-S444.

10. Berger LM, Font SA. The role of the family and family-centered programs and policies. Future Child. 2015;25: 155-176.

11. Internal Revenue Service. Individual Income Tax Returns 2014 [Internet]. 2016 Aug. Report No.: Publication 1304. Available: https://www.irs.gov/uac/soi-tax-stats-individualincome-tax-returns-publication-1304-complete-report\#_download

12. Gassman-Pines A, Hill Z. How Social Safety Net Programs Affect Family Economic WellBeing, Family Functioning, and Children’s Development. Child Dev Perspect. 2013;7: 172-181. doi:10.1111/cdep.12037

13. Meyer BD. The Effects of the Earned Income Tax Credit and Recent Reforms. Tax Policy Econ. 2010;24: 153-180. doi:10.1086/649831

14. Dahl GB, Lochner L. The impact of family income on child achievement: Evidence from the earned income tax credit. Am Econ Rev. 2012;102: 1927-1956. 
15. Hoynes H, Miller D, Simon D. Income, the Earned Income Tax Credit, and infant health. Am Econ J Econ Policy. 2015;7: 172-211.

16. Strully KW, Rehkopf DH, Xuan Z. Effects of prenatal poverty on infant health state earned income tax credits and birth weight. Am Sociol Rev. 2010;75: 534-562.

17. Hoynes H, Patel AJ. Effective policy for reducing inequality? The earned income tax credit and the distribution of income [Internet]. National Bureau of Economic Research; 2015. Available: http://www.nber.org/papers/w21340

18. Hoynes H, Patel A. Effective Policy for Reducing Inequality? The Earned Income Tax Credit and the Distribution of Income [Internet]. Cambridge, MA: National Bureau of Economic Research; 2015 Jul. Report No.: w21340. doi:10.3386/w21340

19. Neumark D, Shirley P. The Long-Run Effects of the Earned Income Tax Credit on Women's Earnings. National Bureau of Economic Research; 2017.

20. Jones LE, Michelmore K. The Impact of the Earned Income Tax Credit on Household Finances. J Policy Anal Manage. 2018;37: 521-545. doi:10.1002/pam.22062

21. Bastian J, Jones M. Does the EITC Pay for Itself? Washington, D. C.: Association for Public Policy Analysis and Management; 2018.

22. Bruch SK, Meyers MK, Gornick JC. The consequences of decentralization: inequality in safety net provision in the post-welfare reform era. Soc Serv Rev. 2018;92: 3-35. doi:10.1086/696132

23. Cooper DH, Lutz BF, Palumbo MG. The role of taxes in mitigating income inequality across the US states. Natl Tax J. 2015;68: 943.

24. National Conference of State Legislatures. Tax Credits for Working Families: Earned Income Tax Credit (EITC) [Internet]. 2018 [cited 14 May 2018]. Available: http://www.ncsl.org/research/labor-and-employment/earned-income-tax-credits-forworking-families.aspx

25. U.S. Census Bureau. U.S. Census Bureau QuickFacts: Oregon [Internet]. n.d. [cited 13 Mar 2019]. Available: https://www.census.gov/quickfacts/fact/table/US,or/INC910217

26. Reddy R, Morris D, Scott E, Bussel B, Dyer S. The High Cost of Low Wages [Internet]. Eugene, OR: Labor Education Research Center; 2014. Available: http://blogs.uoregon.edu/lerc2/files/2017/03/High-Cost-of-Low-Wages-2014-2b332s0.pdf

27. Oregon Early Learner. Oregon Early Learners Facts \& Findings: Multnomah County [Internet]. Corvallis, OR: Oregon State University; 2017. Available: https:/health.oregonstate.edu/early-learners/early-care-education/counties 
28. Education Week. Called to Account: State Highlights Oregon [Internet]. Bethesda, MA: Education Week Research Center; 2016. Available:

http://www.edweek.org/media/ew/qc/2016/shr/em16shr.or.h35.pdf.

29. Diaz G, McClelland M. Family demographic factors and school readiness: Variation by Spanish-speaking ELLs. Austin, TX; 2017.

30. Wanless SB, McClelland MM, Tominey SL, Acock AC. The influence of demographic risk factors on children's behavioral regulation in prekindergarten and kindergarten. Early Educ Dev. 2011;22: 461-488.

31. Jackson JA, Smit E, Manore MM, John D, Gunter K. The family-home nutrition environment and dietary intake in rural children. Nutrients. 2015;7: 9707-9720.

32. Office of the Governor Kate Brown. The Children's Agenda: Pathways Out of Poverty for Children to Achieve Their Full Potential [Internet]. Salem, OR: State of Oregon; 2018. Available: https://www.oregon.gov/gov/policy/Documents/Children’s\%20AgendaGOVERNOR\%20KATE\%20BROWN.pdf

33. Center for Budget and Policy Priorities. State Fact Sheets: Trends in State TANF-to-Poverty Ratios [Internet]. 2017. Available: http://www.cbpp.org/research/state-fact-sheets-trends-instate-tanf-to-poverty-ratios

34. Edwards M. Food Insecurity in Western Us States: Increasing Collaboration Between State Agencies and Nonprofit Organizations. Food Cult Soc. 2012;15: 93-112. doi:10.2752/175174412X13190510222020

35. Cunnyngham K. Reaching those in need: estimates of state supplemental nutrition assistance program participation rates in 2014 (brief). Mathematica Policy Research; 2015.

36. Edwards M, Heflin C, Mueser P, Porter S, Weber B. The great recession and SNAP caseloads: a tale of two states. J Poverty. 2016;20: 261-277.

37. Jardim E, Long MC, Plotnick R, van Inwegen E, Vigdor J, Wething H. Minimum Wage Increases, Wages, and Low-Wage Employment: Evidence from Seattle [Internet]. National Bureau of Economic Research; 2017 Jun. Report No.: 23532. doi:10.3386/w23532

38. Romich JL. Is raising the minimum wage a good idea? Evidence and implications for social work. Soc Work. 2017;62: 367-370.

39. Romich JL, Allard SW, Obara EE, Althauser AK, Buszkiewicz JH. Employer responses to a city-level minimum wage mandate: early evidence from seattle. Urban Aff Rev. 2018; 1078087418787667.

40. Oregon Department of Revenue. Working Family Household and Dependent Care Credit [Internet]. 2017 [cited 29 Mar 2017]. Available: https://www.oregon.gov/DOR/programs/individuals/Pages/working-family-creditinformation.aspx 
41. Family Impact Institute. Family Impact Seminars: Oregon [Internet]. 2018 [cited 14 May 2018]. Available: https://www.purdue.edu/hhs/hdfs/fii/state-seminars/oregon/

42. Oregon State University. Two-generation Approaches to Reduce Poverty [Internet]. Corvallis, OR: Hallie E. Ford Center for Healthy Children and Families; 2015. Available: http://health.oregonstate.edu/hallie-ford/family-impact-seminar-series

43. Bradbury B, Corak M, Waldfogel J, Washbrook E. Too many children left behind: The US achievement gap in comparative perspective. New York: Russell Sage Foundation; 2015.

44. Waldfogel J. The role of out-of-school factors in the literacy problem. Future Child. 2012;22: 39-54.

45. Ruggles S, Genadek K, Goeken R, Grover J, Sobek M. Integrated Public Use Microdata Series: Version 6.0 [dataset] [Internet]. Minneapolis, MN: University of Minnesota; 2015. Available: http://doi.org/10.18128/D010.V6.0

46. Fox L. The Supplemental Poverty Measure: 2016. Washington D.C.: US Census Bureau; 2017. Report No.: P60-261.

47. CPS IPUMS. Description of Total SPM Resources [Internet]. [cited 1 Feb 2019]. Available: https://cps.ipums.org/cps-action/variables/SPMTOTRES\#description_section

48. Wheaton L. The Effect of Different Tax Calculators on the Supplemental Poverty Measure. Urban Institute; 2016 Apr.

49. Wimer C, Mattingly M, Kimberlin S, Fisher J, Danielson C, Bohn S. Using Tax Policy to Address Economic Need. Palo Alto, CA: Stanford Center on Poverty and Inequality; 2016.

50. Tiehen L, Jolliffe D, Gunderson C. Alleviating poverty in the United States: The critical role of SNAP benefits. US Department of Agriculture, Economic Research Service; 2012.

51. Jolliffe D, Gundersen C, Tiehen L, Winicki J. Food stamp benefits and child poverty. Am J Agric Econ. 2005;87: 569-581.

52. Foster J, Greer J, Thorbecke E. A class of decomposable poverty measures. Econom J Econom Soc. 1984; 761-766.

53. Rainwater L, Smeeding TM, Coder J, Vleminckx K, Smeeding TM. Poverty across states, nations, and continents. Child Well-being, Child Poverty and Child Policy in Modern Nations: What Do We Know? 2000.

54. Gornick JC, Jäntti M. Child poverty in cross-national perspective: Lessons from the Luxembourg Income Study. Child Youth Serv Rev. 2012;34: 558-568. doi:10.1016/j.childyouth.2011.10.016

55. Rothwell DW, McEwen A. Comparing child poverty risk by family structure during the 2008 Recession. J Marriage Fam. 2017;79: 1224-1240. doi:10.1111/jomf.12421 
56. Danziger SK. The decline of cash welfare and implications for social policy and poverty. Annu Rev Sociol. 2010;36: 523-545.

57. Moffitt R. The deserving poor, the family, and the u.s. welfare system. Demography. 2015;52: 729-749. doi:10.1007/s13524-015-0395-0

58. Oregon Center for Public Policy. Bi-partisan bill would boost tax credit for working families - Oregon Center for Public Policy [Internet]. 7 Mar 2019 [cited 13 Mar 2019]. Available: https://www.ocpp.org/2019/03/07/bipartisan-eitc-boost-tax-credit/

59. Duncan GJ, Morris PA, Rodrigues C. Does money really matter? Estimating impacts of family income on young children's achievement with data from random-assignment experiments. Dev Psychol. 2011;47: 1263.

60. Moffitt R. The Great Recession and the social safety net. Ann Am Acad Pol Soc Sci. 2013;650: 143-166.

61. Bitler M, Hines AL, Page M. Cash for Kids. Russel Sage Found J Soc Sci. 2018;4.

62. Shaefer HL, Collyer S, Duncan G, Edin K, Garfinkel I, Harris D, et al. A universal child allowance: a plan to reduce poverty and income instability among children in the united states. RSF. 2018;

63. Oregon Center for Public Policy. Oregon’s Low EITC Participation Leaves Over $\$ 100$ Million Unclaimed - Oregon Center for Public Policy [Internet]. 2017 [cited 11 May 2018]. Available: https://www.ocpp.org/2017/01/24/fs20170124-oregon-eitc-participation-use-rate/

64. Oregon Department of Revenue. Oregon Personal Income Tax Statistics: Characteristics of Filers. Salem, OR: Oregon Department of Revenue; 2018.

65. Meyer BD, Mittag N. Using linked survey and administrative data to better measure income: Implications for poverty, program effectiveness and holes in the safety net. National Bureau of Economic Research; 2015.

66. Meyer BD, Mok WK, Sullivan JX. Household surveys in crisis. J Econ Perspect. 2015;29: 199-226.

67. Parolin Z. The Effect of Benefit Underreporting on Estimates of Poverty in the United States. Soc Indic Res. 2019; doi:10.1007/s11205-018-02053-0

68. Stevens K, Heggeness M, Fox L, Pacas J. Precision in Measurement: Using SNAP Administrative Records to Evaluate Poverty. Chicago: Association for Public Policy, Analysis, and Management; 2017. Available: https://appam.confex.com/appam/2017/webprogram/Paper23277.html

69. Urban Institute. Transfer Income Model TRIM3 [Internet]. 2018 [cited 11 May 2018]. Available: http://trim3.urban.org/T3Welcome.php 
70. Steiner Hayward E. SB398 Relating to increased employee awareness of the earned income tax credit; and prescribing an effective date [Internet]. 398 2017. Available:

https://olis.leg.state.or.us/liz/2017R1/Measures/Overview/SB398

71. Rueben KS, Sammartino F, Stark KJ. Upward mobility and state-level eitcs: evaluating california’s earned income tax credit. Tax Law Rev. 2017;70: 36.

72. Feenberg D, Coutts E. An Introduction to the TAXSIM Model. J Policy Anal Manage. 1993;12: 189. doi:10.2307/3325474

73. Bohn S, Danielson C, Levin M, Mattingly M, Wimer C. The California Poverty Measure: A New Look at the Social Safety Net. 2013 Oct p. 72. 


\section{Supporting Information}

S1 Appendix. Phase-in and Phase-out of the Federal Earned Income Tax Credit, the Oregon Earned Income Credit and the Oregon Earned Income Credit Supplement for Families with Young Children. Solid lines represent credits for single, head of household, or qualifying widow(er) with 2 children. Dotted lines represent credits for married couples filing jointly with 2 children.

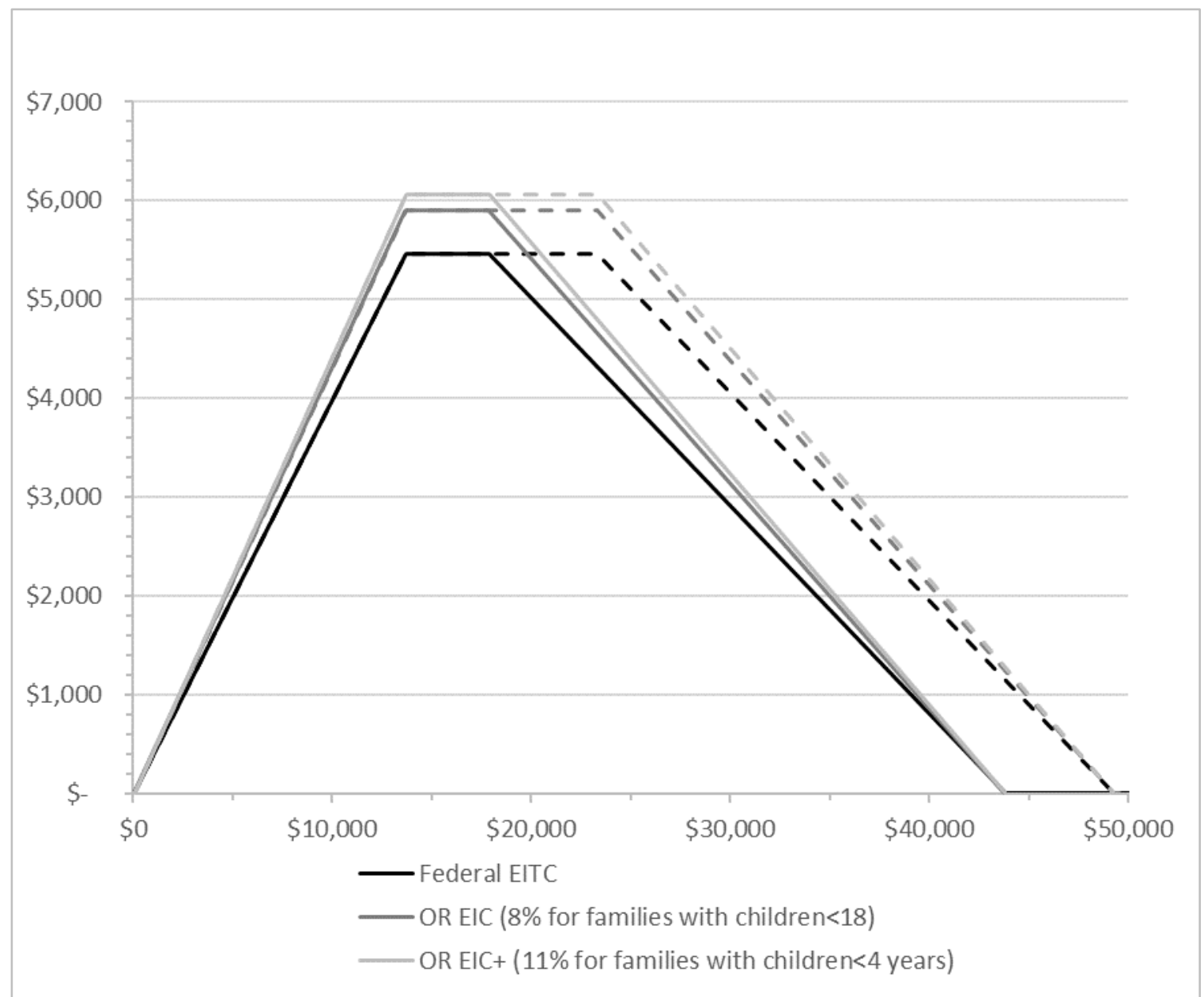

Data source: US Department of the Treasury, Internal Revenue Service. Publication 596 (Cat. No. 15173A): Earned Income Credit (EIC) 2014 


\section{S2. Appendix. Note on Differences in Poverty Measurement and Survey Data Sources}

In previous iterations of this project, we used the American Community Survey (ACS) and examined the OEIC impact on OPM. OEIC and other tax values are not reported in the ACS. To include taxes, we submitted the Oregon sample from the ACS through the TAXSIM model developed by the National Bureau of Economic Research. TAXSIM is a cluster of software programs and data that allows researchers to generate a microsimulation model of federal and state tax systems [72]. Following state-level poverty measure efforts [73], we then imputed TAXSIM estimates of federal and state taxes. Table S2 shows a summary of ACS results. Similar to the main results, overall changes to child poverty and young child poverty from the OEIC were not statistically significant at the $5 \%$ level. Additional results can be made available upon request.

\begin{tabular}{|c|c|c|c|c|c|}
\hline \multicolumn{6}{|c|}{$\begin{array}{l}\text { Table S2. Child Poverty Level, Depth and Severity under Currer } \\
\text { Group }\end{array}$} \\
\hline & $\begin{array}{l}\text { MI } \\
(1)\end{array}$ & $\begin{array}{l}\text { OPM } \\
\text { (2) }\end{array}$ & & $\begin{array}{c}\text { EITC+OEIC } \\
\text { (4) }\end{array}$ & $\begin{array}{l}\text { Prop. } \Delta \\
\text { (5) }\end{array}$ \\
\hline All children (age $<18$ ) & 26.2 & 20.86 & 17.52 & 17.34 & -1.03 \\
\hline Young children (age<4) & 28.39 & 24.84 & 21.38 & 21.14 & -1.12 \\
\hline \multicolumn{6}{|c|}{$\begin{array}{l}\text { MI/FPL = market income poverty rate, or percent of children in families whose market incomes were } \\
\text { less than the Official Poverty Threshold (FPL). The MI/FPL does not include cash transfers. } \\
\text { OPM = poverty rate (Official Poverty Measure). The OPM includes cash transfers, but does not } \\
\text { include EITC or OEIC. } \\
\text { EITC = poverty rate, with EITC } \\
\text { OEIC = poverty rate, with EITC and OEIC } \\
\text { Proportional change refers to the proportional difference between the poverty rate with EITC } \\
\text { only and poverty rate with EITC and OEIC. } \\
\text { Data source is American Community Survey } 2015\end{array}$} \\
\hline
\end{tabular}

The CPS data and SPM measure of poverty were selected for the current study based on three reasons. First, poverty rates - both OPM and SPM - are derived from the CPS and not the 
ACS. Second, the SPM is widely recognized as a more valid poverty measure, mainly because it include more accurate definitions of family and household resource sharing, includes of various noncash transfer and tax credits as resources, subtracts tax payments and medical and work expenses from resources, and adjusts for regional differences in the cost of living. Third, the SPM officially includes tax credits such as the EITC and state EITC tax credits. 